\title{
Russia in the Balkans: Great Power Politics and Local Response
}

\author{
VSEVOLOD SAMOKHVALOV
}

ABSTRACT The present paper looks into the current policies of Russia in the Balkans. It argues that after a short period of withdrawal from the region, Moscow is currently making efforts to regain its position and, in some sense, it has been a quite successful come-back. Russia has enhanced its economic presence, political clout, and symbolic influence in some of the countries of the region. However, Russia's present return to the Balkans is of a quite different nature than its past engagement there as Moscow has now moved to a more assertive foreign policy. The paper also looks at the response of the Balkans countries to Moscow's policies. It argues that the Balkans countries have adopted a more pragmatic approach to relations with Russia and as a result, Russia and these countries are in the process of finding a new, workable modus operandi for their interaction.

\section{Introduction ${ }^{1}$}

$\mathbf{T}$ his paper sets out to analyze Russia's position in the Balkans. The departure points for the paper are several problematic factors. Firstly, it has often been argued that Russia's identity as a great power shapes its assertive foreign policy. ${ }^{2}$ While this might be true in Russia's relations with West, this type of account discards all the cases of collaborative Russian-Western interaction. Secondly, most analyses of Russian foreign policy tend to discard geographic variance in Russian foreign policy. One of the most obvious examples could be the striking contrast between Russia's active opposition to perceived Western expansion in the Black Sea region, as opposed to its indifference to Chinese penetration into Central Asia. ${ }^{3}$ Driven on this problematique, the paper will seek to explore the meaning of the Balkan region for Russia's identity. Thirdly, Russian foreign policy is often analyzed by scholars working on Russian foreign policy in various regions; less attention has been paid to the response of these countries to Russian policies. Such a narrow perspective often misses the important input that the countries of the region provide to shaping the outcome of regional politics.

*Vesalius College, Belgium 2019, pp. 189-210 
When Russia reappeared on the international scene as a new, independent actor in the early 1990s, its policies in the region were shaped by its relationship with Europe. Unlike previous periods, Moscow was less interested in imperial expansion
To address this, the paper proceeds as follows. First, it will explore the ideational background of Russian foreign policy and Russian perceptions of the Balkans. I will draw on these findings to understand how certain perceptions constituted possible and thinkable policy options. Additionally, I will seek to identify how Moscow's policies in the region have been shaped by the Russian-Western relations. Secondly, it will analyze Russian foreign policy in the region as it evolved from the 1990s to 2000s. In particular, it will look into the evolution of Russia's attitude toward the region in the context of Russian-Western relations. Thirdly, it will look at the response of the countries of the region to Russian foreign policy, and how this response has shaped the regional constellation in the Balkans. In particular, the paper will consider the political and economic dimensions of this interaction.

\section{Russia and the Balkans: Historical Imaginaries}

Many writings have focused on Russia's great power identity to highlight that the Balkans are important for Russia. This definition, while partially true, often implies that Russia pursues policies aiming to support "fraternal" Slavonic or Orthodox nations (Serbs, Montenegrins, Bulgarians, and Greeks) in their fight against external oppressors (the Ottoman Empire, Austro-Hungary, Germany, or, in modern days, the U.S. and NATO). ${ }^{4}$ The equation between Russia's great power identity and its special relations with the Balkan nations has rarely been properly analyzed. ${ }^{5}$ Indeed, one can agree that the Balkans have played an important role in the formation of Russia's identity. In analyses of Russian literature, textbooks, and official documents, the Balkans are most often mentioned as the place through which Russia became a state and a European great power. The Balkans are repeatedly constructed as the place where Russia borrowed all of the sacral features of its stately-existence (Christianization, cultural artefacts, the double-hedged eagle, the title of the Russian Tsars all coming from the Black Sea and Mediterranean). No other part of Russia's vast territory or periphery - not even the Baltics or the huge spaces of Siberia and the Pacificare mentioned as frequently or given such importance as the Balkans. ${ }^{6}$

At the same time, Russia's great power identity does not necessarily mean that Russian policymakers feel strong moral obligations toward the Balkan nations (some romantic nationalists in Russia might, but not the policymakers 
in the Kremlin). Indeed, Moscow (or rather St. Petersburg as the capital of the Russian Empire) entered into situational alliances with the Balkan insurgents when it needed their support in its expansion to the Black Sea and the Mediterranean. However, such situational alliances did not necessarily mean any special emotional or spiritual bond between Russia and the Balkans nations. As recently acknowledged by a Russian scholar, even Catherine the Great's Greek plan, which has often been construed as Russia's commitment to create an independent Greece, in reality turned into a small-scale military operation under Count Orloff, aimed merely at setting up a naval presence in the region and not waging a major liberation war for Greece. ${ }^{7}$ Later on, Russia was prepared to undermine or act against some of these nations when they became too strong, as was the case in Russian-Bulgarian relations in the late $19^{\text {th }}$-early $20^{\text {th }}$ century. A similar approach was obvious in Stalin's attempt to subordinate Yugoslav leadership after WWII, which resulted in to the Soviet-Yugoslav rift in the early Cold War period. Therefore, one could argue that in the Russian Imperial period or early Soviet era, Moscow relied on the support of the Balkan nations in its pursuit of its policies without necessarily attaching sacred sentiments to this relationship. As a broader generalization, Russia's relationship with the Balkans was rather a function of the primary goals of Russian foreign policy -imperial expansion and great power politics in Europe.

When Russia reappeared on the international scene as a new, independent actor in the early 1990s, its policies in the region were shaped by its relationship with Europe. Unlike previous periods, Moscow was less interested in imperial expansion (in fact, it sought to prevent territorial shrinking and institutional implosion). What Russia was more concerned about in the early 1990s was to remain among the major European great powers, i.e. to be accepted into the club of great powers. While Moscow could not rely on its material capabilities in pursuit of such a status, it could still sustain such claims by contributing or participating in the great power concerts that decided the fates of the Balkan nations. ${ }^{8}$ Indeed, Russia still used historical narratives to maintain its place in the great power deliberations about the Balkans.

This modus operandi was openly voiced by senior Russian politicians and diplomats in the Balkans. President Yeltsin argued that Russia should build its policy on the basis of Russia's great power relations with the West. ${ }^{9}$ During the war in Bosnia, Vitaliy Churkin, the Russian envoy to the Balkans, made it explicitly clear that Moscow valued its cooperation with the West more highly than the map of Bosnia. ${ }^{10}$ In 1995, Russia supported the Dayton Agreement despite the fierce protests of Bosnian Serbs. This policy continued after the much-criticized liberal period of Russian foreign policy (1991-1995). Under the 'statist' foreign minister Evgheniy Primakov, Russia supported and even actively took part in the military operations which effectively squeezed the most popular and radical leaders such as Radovan Karadzic from the Bosnian leadership and 


\section{Russia is more concerned about being recognized and included in the great power concerts than about negotiating arrangements for the failing states in the Balkans}

deprived them of media resources in $1996-1998 .{ }^{11}$ During the NATO intervention in Kosovo, Russia did not seriously consider providing military support to Yugoslavia. Apart from symbolic actions such as the U-turn of the plane by Prime Minister Primakov and some intelligence sharing, Moscow's primary rationale was to maintain its role among the great powers and return the situation to the negotiating table, where Russia would be one of major mediators. Even the 'epic march' of the Russian peace-keeping battalion from Bosnia to the Kosovo airport sought more to secure Russia's presence in the region than to challenge the Western military operation.

While NATO intervention in Kosovo is often mentioned as one of the turning points in Russia-Western relations, such interpretations could not explain why President Putin decided to support the U.S. operation in Afghanistan and help Washington gain basing rights in Central Asia. Moreover, after and despite the Kosovo crisis, President Putin raised the issue of a potential Russia application to NATO in 2002. Similarly, under President Putin, Russia was prepared to accept an independent status for Kosovo -if the West had properly worked with Moscow and allowed sufficient time to prepare the local public opinion. However, the information was leaked from the negotiation room and became public, forcing Moscow to disavow such a possibility. ${ }^{12}$ These decisions suggest that Russia is more concerned about being recognized and included in the great power concerts than about negotiating arrangements for the failing states in the Balkans. The sections below suggest that Russia's policy in the Balkans is an outcome of this quest for recognition by the West -recognition that the West has often refused to grant. It reveals the limit where Russia would stop from seeking engagement with the West.

\section{Claiming Great Power Status}

The fact that Russia's policies in the Balkans are often defined and envisaged through the prism of Russia-Western relations becomes obvious upon a cursory look at the Russian foreign policy doctrine of 2016. While the document is full of references to the West, the U.S., Europe, and Asia, the Western Balkans are never mentioned. ${ }^{13}$ This, according to Russian researchers, reflects the state of interests and opinions about the region. ${ }^{14}$ At the same time, one cannot 



\section{Russia was not opposed to the agreement between Athens and Skopje per se, but it was frustrated that the deal was done without Moscow's consent, and that it was linked to NATO's further expansion in the Balkans}

rather seeks to socialize the West into recognizing Russia as an equal partner. It creates or manipulates instability to demonstrate that Western policies adopted without Russia are doomed to fail. But these measures fall short of being defensive Realpolitik. As one Russian analyst states, "Russia is keen, however, to take advantage of the deep-rooted local problems to make the Western Balkans a thorn in the West's side, while posing as an influential world power." ${ }^{18}$ In particular, Moscow seeks to undermine the West's state-building efforts in the Balkans. Within this logic, Russia has blocked any substantive progress in resolving the Kosovo issue by supporting the intransigent position of Serbia, and has blocked the process of recognizing the independence of Kosovo. It has also supported the radical positions among the Serb leadership and local communities in the North. Furthermore, the Kremlin-affiliated oligarch Konstantin Malofeev has arranged moral and financial support for the autonomy-minded leader of the Republika Srpska in Bosnia and Herzegovina, Milorad Dodik. ${ }^{19}$

Additionally, while the NATO enlargement to the Balkans did not constitute a direct threat to Russia, Moscow still sought opportunities to destabilize the situation to prevent the West from feeling confident on the ground. These tactics targeted even the well-established and Russian-friendly countries of the region. ${ }^{20}$ For example, when the government of Montenegro decided to start the process of integration into NATO, a Russia-led network of military intelligence organized a coup attempt in Montenegro. After the coup failed, the Kremlin was forced to send high-flying security official Nikolay Patrushev, Head of the National Security Council, for a 'damage-control' mission. It shows that, even while losing the symbolic battle over Montenegro's NATO membership, Moscow sought to maintain some sort of political influence in the Balkans. A similar approach informed Russia's response to the rapprochement between Athens and Skopje, as they finally moved to resolve the dispute over the name of the Former Yugoslav Republic of Macedonia (FYROM) after a more than 25year deadlock. Thanks to the Prespa Agreement reached by the Prime Minister of FYROM Zoran Zaev and his Greek counterpart Alexis Tsipras, the country received a new name -Republic of North Macedonia- and an invitation to start talks about entering NATO. Russia was not opposed to the agreement between Athens and Skopje per se, but it was frustrated that the deal was done without Moscow's consent, and that it was linked to NATO's further expansion in the Balkans. It tried to depict Western efforts in the region as $19^{\text {th }}$ century great power geopolitics. Russian Foreign Minister Sergey Lavrov personally 
floated a conspiracy theory about a potential partition of North Macedonia being discussed by Albania and Bulgaria. ${ }^{21}$

Since the Prespa Agreement opened the door for North Macedonia's accession to NATO and highlighted Russia's exclusion, Moscow again sought to destabilize Greek-Macedonian relations. Ivan Savvidis, a Russia-affiliated tycoon, instigated and financed serious protests against the deal. Russia-born tobacco-producer Ivan Savvidis had repatriated to Greece and since the early 2000s expanded his economic presence in the Northern Greece. His economic activities had a peculiar character as they were designed to enhance his political influence. Savvidis bought and invested in the local football club PAOK and in local media. ${ }^{22}$ His investment in cultural and infrastructure projects brought him influence in the highly militant and mobilized Pontian Greek community (repatriates from Russia) and some radical nationalist groups. In June, various actors reported that Savvidis had instigated and sponsored mass protests against the Prespa Agreement on both sides of the Greek-Macedonian border. Importantly, to organize protests in Skopje, Savvidis drew on the fan-base of the local football club 'Vardar,' owned by another Russian businessman Sergei Samsonenko. Samsonenko, who unlike Savvidis had a very low profile in the Russian business world, suddenly moved to Macedonia in 2006 and quickly evolved into a major business/social player. He bought two sport clubs, and invested in constructing sport arenas and hotels in Skopje's city center. Serving as Honorary Consul of Russia, Samsonenko worked closely with the local pro-Russian part of the leading political party bloc VMRO and had numerous meetings with VMRO Prime Minister Grujevski. ${ }^{23}$ Ahead of the elections, Samsonenko openly supported VMRO and even participated in their electoral campaign. ${ }^{24}$ Moreover, he criticized pro-Western Premier Zoran Zaev. ${ }^{25}$

Ultimately, the Greek government opened an investigation against Savvidis and the businessman had to flee. ${ }^{26}$ The Prespa Agreement was pushed through even though other members of the Russian-speaking community in Northern Greece sought to torpedo the deal by holding numerous rallies against it in Athens and Thessaloniki. When it became clear that the agreement, reached without Russia, would pave the way to North Macedonia's membership in NATO, Russian Foreign Minister Lavrov accused the West of interfering in the internal affairs of the Balkan nations. ${ }^{27}$ However, when it became clear that it was impossible to revert the deal, the Russian minister made a U-turn to preserve Russia's image, claiming that Moscow has never been against a Greek-Macedonian compromise and only opposed any externally imposed policies. ${ }^{28}$ The 'Macedonia' dispute reveals the mixed nature of Russia's policies in the region, i.e. to seek the West's acceptance of Russia's position, disrupt as much as it can to regain recognition, and if this policy fails to bandwagon with the West, but to seek opportunities to undermine the West's primacy in its projects in the Balkans. 
Several conclusions can be drawn from the above. Firstly, Russia's policies in the Balkans (both Western and Eastern) feature a targeted and very selective engagement with the region. Moscow clearly seeks to increase its presence there. Russian- and Kremlin-affiliated businessmen have made significant investments in specific politically-influential spheres (sports, media, gambling, the church, energy). While formally driven by private initiatives, this presence tends to be turned into a tool of Russian policy or even used to destabilize the region and/or to undermine Western policies. Secondly, Russia's policy in the Balkans reveals a new emerging feature of decision making in the Kremlin that could be described as 'outsourcing' and 'multi-actor.' Even though President Putin clearly controls the Russian state and security apparatus, some analysts note that -in a departure from Soviet foreign policy- he currently balances between various groups of influence. He also allows competition between them and allocates certain resources for ad hoc, bottom-up foreign policy initiatives. Among these groups one can identify major structures such as political police and intelligence (Federal Security Service) and military intelligence (GRU). But the circle of policy entrepreneurs is not limited to official state bodies. It also includes various non-state actors, i.e. business people (such as Kremlin-affiliated businessmen Evgheniy Prigozhin, with allegedly tight links to the private military company 'Vagner'), ideological groups (Christian-civilizational ideologues represented by oligarch Konstantin Malofeev), or even individual senior policymakers such as Putin's long-standing advisor on Eurasian affairs Sergei Glazyev. These actors often come up with various foreign policy initiatives and request -and sometimes gain- Kremlin support. This decision making process constitutes a fundamental change in Putin's foreign policy. This type of initiative helps the Russian leader manage elite groups and maintain plausible deniability in case of failures (such as the attempted coup in Montenegro or Savvidis' activities in Northern Greece). On the other hand, this approach often lacks a certain coherence and professionalism and undermines Russia's image of strong and omnipotent security-state. Moscow is increasingly seen as a strong but unpredictable and incoherent actor. Even most Russophile governments in the Balkans have come to the realization that dependence and reliance on such a partner should be limited and clearly-bounded.

\section{Limits of Greatness: Russia's Policies, Western Counter-Measures, and Local Response}

The case of Bosnia is probably the classic example of Russia's effort to generate instability in the region. While in the early days of post-war reconciliation Russia played some constructive role in reconstructing the war-torn country and quickly bringing energy supply to Bosnian towns and cities, in the past decade the Kremlin has sought to prevent deeper integration within the country. From the early 2000s, the Russian energy company Gazprom, which took over 
the major enterprises in the Republika Srpska (RS), has prevented the integration of the energy systems of the Bosniak-Croat Federation and the Republika Srpska, the two entities created by the Dayton Peace Accord. $^{29}$ Russia had repeatedly supported Milorad Dodik, leader of the Republika Srpska (a Serb entity comprising Bosnia and Herzegovina), who was planning to run a referendum on the independence of RS. Dodik received the support of the Russian President (who fre-

\section{Developments in Bosnia and the response of the Euro- Atlantic community shows that pro-Russian leaders in the region should possess a very high degree of integrity and reputation, and not fall under Western pressure in pursuit of their own nationalist agenda}

quently met the leader of RS) as well as the financial backing of Kremlin-affiliated businessmen and Russia-sponsored official and social media. Moscow provided trainings for Dodik's personal paramilitary force, the 'Serbian Honor', hosting them both in Russia and in the 'Russian-Serb Humanitarian Centre' in Nis. To facilitate the further disintegration of Bosnia, Russia also supported Croatian separatism within the second major constitutive part of the country, the Bosniak-Croat Confederation. One of the radical leaders of the Croatian community in Bosniaand co-president of the Bosnian collective Presidency Dragan Čović received generous financial and political support from Russia. ${ }^{30}$ When Čović spoke about the Croatian Community leaving the Federation to create its own state, the Russian Ambassador to $\mathrm{BiH}$ immediately labelled it a 'Croatian question,' which has become a reality to live with. ${ }^{31}$

However, despite Russian support of radical ethno-nationalist discourse, there are clear limits to the use of this instrument. The fact that Russia relies on non-transparent and often dubious channels of funding has made many of its allies in the Balkans vulnerable to sanctions and public scandals. After the EU came up with a negative response to the potential scenario of a referendum and the U.S. imposed sanctions against Dodik, the Bosian Serb leader quickly softened his rhetoric about independence. ${ }^{32}$ After a similar financial scandal linked him to Russian investors, the Bosnian Croat leader Čović lost the elections to the more moderate leader of the Democratic Front Zeljiko Komsic, who ran on more inclusive slogans of civic nationalism in Bosnia. ${ }^{33}$ Developments in Bosnia and the response of the Euro-Atlantic community shows that pro-Russian leaders in the region should possess a very high degree of integrity and reputation, and not fall under Western pressure in pursuit of their own nationalist agenda. But even in such a case, most ethno-nationalist forces cannot but see that potential scenarios of radicalization might eventually increase personal risks to their popularity or power. Therefore, they seem to look for a mix between ethno-nationalist rhetoric and practical policy, which 


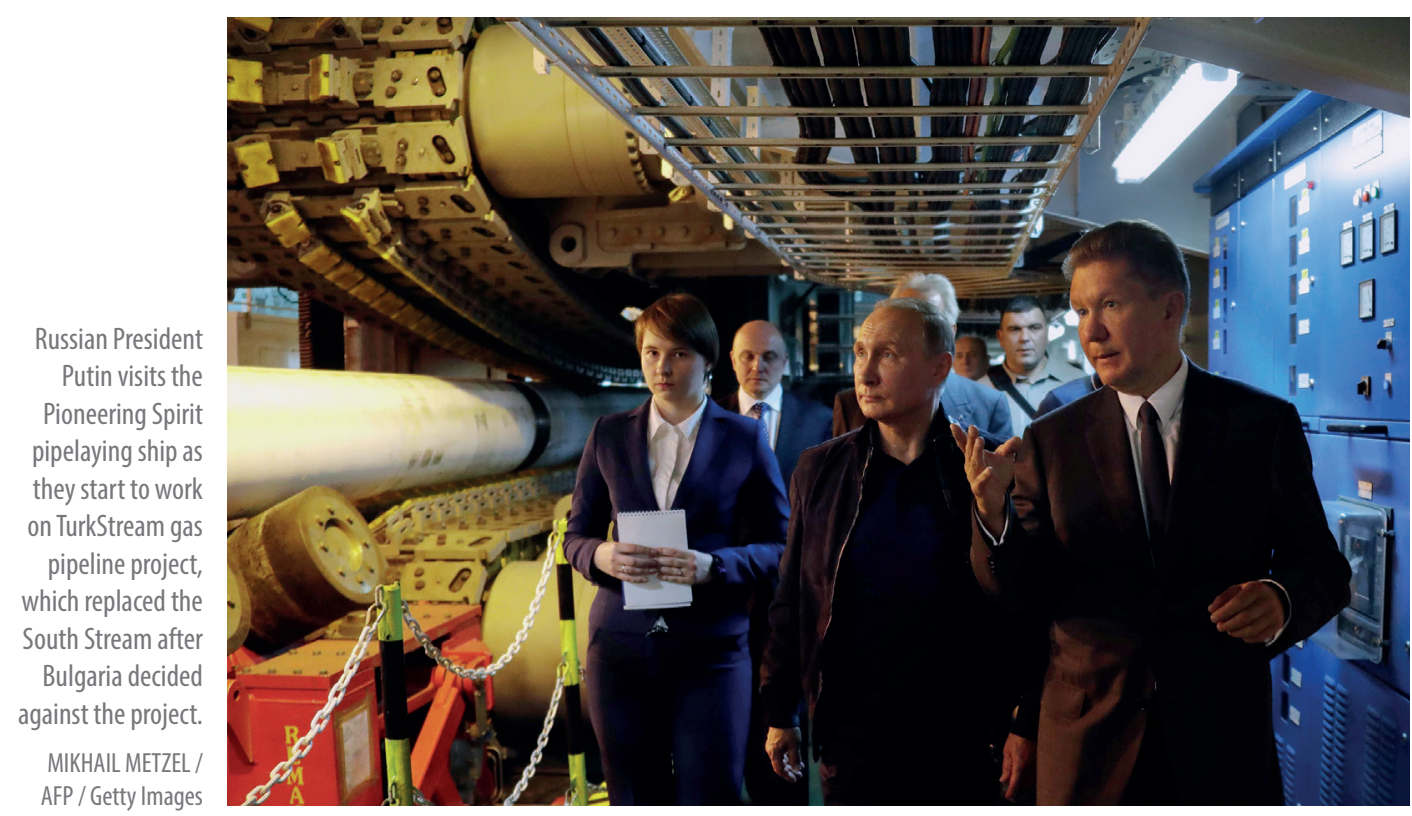

would prevent them from being trapped in a radicalization spiral. In other words, Russia's allies in the Balkans would be happy to use Russian money and separatist slogans to build popularity, but are not prepared to burn their own political capital and lose control over their own countries as a result of Russia's great power ambitions.

The case of Serbia displays a clear difference between the rhetorical and factual power balance in the region. On the one hand, President Vučić speaks highly of the Russian leader and explicitly excludes mention of any future membership in NATO. Moreover, the two leaders highlight the long-standing spiritual and cultural bonds between the two states. The Serb Orthodox Church clearly took Russia's side in its dispute with the Ecumenical Patriarch about the autocephaly of the Ukrainian Church. ${ }^{34}$ Russian and Serb officials have regularly exchanged gifts and decorated each other for support and services of friendship. ${ }^{35}$ On the other hand, despite numerous statements about the unique Eastern Christian cultural unity and shared negative attitude towards NATO, the current Serb leadership has pursued quite a different policy. For example, Serbia has an extensive interaction with NATO. It has signed a special Individual Partnership Action Plan with NATO, which it has implemented along with a number of other initiatives. ${ }^{36}$ In 2017 alone, Serbia participated in 18 joint exercises with NATO and U.S. troops. Moreover, Serbia signed a Status of Forces Agreement that offered NATO troops diplomatic status and immunity as well as access to Serbian military facilities. ${ }^{37}$ At the same time, Belgrade was reluctant to allow Moscow to turn its comparatively small presence under the 
aegis of an Emergency Ministry in South Serbia into a bigger militarized facility. Additionally, even in the less controversial question of Serbian membership in the EU, President Vučić highlighted that the Russian leader would respect Serbia's path to Europe. ${ }^{38}$

When it comes to less politically visible issues, it becomes even clearer that the current Serbian government has serious concerns about Russia's hybrid activities in the country. For example, Serbia initially allowed Russia to organize a summer camp at the Serb resort of Zlatibor for the patriotic upbringing of Russian-Serb youngsters. ${ }^{39}$ Even though the Serb co-organizer Željko Vukelić tried to position the camp as youth-patriotic work, the Russian co-organizer of the camp was the retired Soviet army



When it comes to less politically visible issues, it becomes even clearer that the current Serbian government has serious concerns about Russia's hybrid activities in the country colonel Valeriy Shambarov, famous for his imperial views; Shambarov stated that the goal of the activities was a military training for youngsters in Serbia. ${ }^{40}$ Shambarov was affiliated with organizations that sent numerous volunteers to the war in the East of Ukraine. While the Serb government could not control the first camp organized in Russia in April 2018, ${ }^{41}$ Serb police demanded that the organizers stop their activities in Serbia. ${ }^{42}$ Similarly, the leadership of the Republika Srpska in Bosnia, while praising Russia's sacrifice in WWII, sought to limit Russia's influence and the presence of Russian actors. For example, the leadership of the Bosnian Serbs banned the Kremlin-affiliated and very visible patriotic bikers gangs the Night Wolves from entering the RS. Instead, the RS created and funded a local replica of the 'patriotic bikers. ${ }^{\text {'4 }}$

Similarly, the case of Greece has demonstrated the limit of Russian-Greek rapprochement. While the two countries enjoyed close relations even at the peak of the Cold War, the last two years have put these relations under pressure. While formally Greek Prime Minister Tsipras spoke highly about President Putin and the effective collaboration between the two countries, Greece still supported sanctions against Russia in the European Council. Greece felt it was being manipulated by Russia when it came to the promotion of energy corridors fully controlled by Moscow. Moreover, Athens was particularly annoyed with Russia's growing political presence and economic investment in one of the Holy Places -a complex of the oldest monastic communities of Eastern Christianity- Mount Athos in Northern Greece. This frustration grew into an open diplomatic scandal, which involved two Russian diplomats and two other Russian officials associated with the Imperial Orthodox Palestine Society (IOPS). IOPS had been re-established by the Russian Parliament in 1992 and has fourteen offices in the Middle East and Europe, including Greece since 2016. ${ }^{44}$ IOPS has been an active promoter of Russia's foreign policy since 2007, when Sergei Ste- 
Some failures of the European state-building policies in the region, and Russia's growing prosperity driven by statecentered economic policies and backed up by the increase in energy prices prompted Russian liberal thinkers as well as some EU member states to question Europe's power of attraction as well as the EU's economic policies in the Balkans pashin, former Prime Minister and the first Head of the Federal Security Service and Federal Counter-Intelligence, was appointed president. ${ }^{45}$ Stepashin sought to develop close contacts with local business- and community-leaders in Northern Macedonia, home to the populous and strong Russian-speaking community of Pontian Greek repatriates from post-Soviet space.

In an unprecedently tough statement, the Greek Foreign Ministry accused Russia of long-standing animosity towards the Greek Church and subversive attempts "to impose the presence of the 'Imperial Orthodox Palestine Society' in Greece, an

organization created by the Czars' secret services in the $19^{\text {th }}$ century with a view to de-Hellenize the patriarchates of the Middle East." ${ }^{36}$ While this harsh statement has often been interpreted as the personal whim of the highly emotional and controversial Greek Foreign Minister Kotzias, ${ }^{47}$ Greece eventually started to impose limitations on the travel of Russian officials and clergy to Northern Greece and access to Mt. Athos was limited. Moreover, Russian and philo-Russian monasteries in Athos were brought under investigation for financial matters. ${ }^{48}$ Despite the traditional anti-Americanism of the country, the Greek government offered the U.S. three new sites for basing rights: Volos, Alexandroupolis, and Larissa. Additionally, the Greek government agreed to host a NATO training center in the south of the country. ${ }^{49}$ All these moves suggest that Russia's policy of return to the Balkans is seriously mitigated by the policies of the Balkan nations which -while reaping the benefits of collaboration-still consider the West to be more attractive in terms of political and security affiliation.

\section{The Economic Dimension}

In the economic domain, Russia has tried to offer the Balkans opportunities to partake in its own economic project. In the 1990s and even in the early 2000s, Moscow seemed to have accepted that -in the economic domain- the EU had the attractive power and transformative capacity to modernize and to bring prosperity to the region. However, some failures of the European state-building policies in the region, and Russia's growing prosperity driven 
by state-centered economic policies and backed up by the increase in energy prices prompted Russian liberal thinkers ${ }^{50}$ as well as some EU member states to question Europe's power of attraction as well as the EU's economic policies in the Balkans. ${ }^{51}$ Consequently, Russia reconsidered its attitude toward Europe's 'transformation through integration' approach.

This reconsideration led Russia to activate its Balkan policies in the economic dimension. Russia sought to highlight the high economic and social costs of European integration for the Balkans and offer an alternative option: deeper trade arrangements with Russia and, potentially, integration with the Russia-led Eurasian Economic Union. For example, Moscow touted alternative economic models and tried to appeal to those parts of the population that were disenfranchised by the neo-liberal economic policies promoted by Europe. Highlighting all of the risks and costs of European integration and offering an alternative to it is the cornerstone of Russia's attitude to the EU activities in the Balkans today. Instead of accepting a role as the European periphery, Russia offered to fight together for a decent place in the global value chain.

One of the most visible instruments of Russia's economic policies is the energy domain. Over the past two decades, Russia has approached the countries of the Balkans, inviting them to support Russia-driven pipeline projects and to become hubs of energy flows to Europe. One of the most recent offers proposed by Russia was the idea of a South Stream pipeline project bringing Russian and Central Asian gas to the European markets. Promoted by the Russian-Italian energy alliance (Gazprom-ENI) since 2007, South Stream was planned to run from Southern Russia under the Black Sea to Bulgaria and then break into branches running through i) Greece-Italy and ii) Serbia-(Slovenia)-Hungary-Austria. The idea had merit, given the fact that transit through Ukraine had been compromised by recurrent crises between Russia and Ukraine, but the project stumbled due to emerging European opposition to energy monopolies in the European markets. Articulated as the 'Third Energy Package, this consensus prohibits energy producers from maintaining major control over transport and downstream capacities. This requirement went against Gazprom's traditional policy -to maintain majority ownership in its pipeline projects. In 2014, the European Commission initiated an infringement procedure against Bulgaria for non-compliance with the Third Energy Package. It should be noted, however, that one of the reasons the EU adopted a tough line against the South Stream was Russia's invasion of Ukraine. ${ }^{52}$ After Bulgaria decided against the project, Russia announced its withdrawal from South Stream ${ }^{53}$ and launched an alternative, TurkStream.

With Turkey, Greece, and Serbia openly joining TurkStream, Russia’s power of economic attraction seems to be growing. At the same time, this victory reveals the limits of Russia's economic attractiveness. It looks as if the countries of the 
The EU has used its power to ensure that all Russia-built pipelines would provide access to third-party gas for transit to Europe, thus neutralizing Russia's potential efforts to use a monopoly over gas pipelines for political purposes region, while accepting Russia's offer, are still trying to do so while remaining in the framework of European economic governance. Even Serbia's decision to join the project was accompanied by Belgrade submitting a formal request to the Secretariat of the European Energy Community in Vienna. ${ }^{54}$ In the case of Greece and Hungary, TurkStream still relies on the existing energy infrastructure, which actually undermines Rus-

sia's plans to back up this energy trade with physical infrastructure, i.e. Russian-owned pipelines. Indeed, Russia's energy offer in the Balkans is not always a welcome development. Firstly, it is associated with the risk of escalating conflict with Europe, which the countries of the region seek to avoid. Secondly, Russia's assertive policy in taking over the oil/gas processing capacities of the countries of the region pushed even the closest Russia's ally -Serbia- to adopt tough measures against Russian energy-giants. ${ }^{55}$ Thirdly, Russia's inclination to link political and economic questions seriously limits the attractiveness of its energy card. One of the most recent examples was Russia's attempts to force Serbia to grant special diplomatic privilege to the site and the workers of the Russian Emergency Ministry in Serbia. When President Vučić refused Russia special treatment, Moscow revoked its promise to grant Serbia a new discount on gas price. While countries struggled not to 'spoil' their relationship with Russia, Belgrade started to look at Russia's energy offers as both an opportunity and a challenge.

Another limiting factor is the fact that Russia's frequent efforts to link energy to political issues has prompted the EU and U.S. to come up with what one can call an 'alternative to the alternative.' While some EU member-states believe that Nord Stream 2 and TurkStream will make Europe less dependent on the Russian-Ukrainian transit, they still seek to create alternatives to Russian supply. Moreover, the U.S. simply exerts pressure on its allies, asking them not to engage with Russia. Both the EU and U.S. are heavily investing in the creation of LNG terminals both in the Balkans and the Baltics. ${ }^{56}$ The EU has used its power to ensure that all Russia-built pipelines would provide access to third-party gas for transit to Europe, thus neutralizing Russia's potential efforts to use a monopoly over gas pipelines for political purposes. Unsurprisingly, Balkan elites share this concern, given that Russian officials tend to treat the Balkans as an underdeveloped periphery.

The Russian state still has significant investment opportunities inside Russia and looks to expand its economic collaboration with the leading European 
countries. As a result, Russia cannot deploy significant financial and human resources to promote collaboration with the Balkans. This became even clearer after the 2008 financial crisis which undermined Russian economic presence in Montenegro. ${ }^{57}$ For example, when Russia worked with Germany to promote the Nord Stream pipeline, it deployed its most skillful lawyers and high-flying officials who patiently worked with German elites to prepare the ground for the deal. On the other hand, in the Balkans, Russia sent far less important and refined cadres to present Russian energy offers, which have failed to build sufficient support for Russia. As a result, energy cooperation is seen rather as a marriage of convenience than a shared success story, and economic interaction with Russia is treated as secondary to interaction with the EU. ${ }^{58}$

Similar dynamics characterize the overall trade dynamics between the countries of the region and Russia. Although Moscow speaks about increasing trade with the countries of the region, in reality, trade is in comparative decline. The volume of trade with Russia is decreasing while Europe is becoming a major trading partner, even in the case of Serbia, Russia's closest regional partner. Moreover, with Serbia progressing on its European integration path, Moscow seems to be prepared to suffer negative consequences. ${ }^{59}$ It seems that the Balkan countries now consider Russia an interesting -but relatively small market. At the same time, the renewed EU membership promise and offer to the Western Balkans to become a major hub for connectivity between Europe and Asia looks like a gateway to the global economy. ${ }^{60}$

The annexation of Crimea and Russia's role in the Ukrainian crisis have resulted in a further deterioration of economic relations between Russia and the Balkan nations. Albania and Montenegro have clearly aligned with the West against Russia by adopting sanctions against Russia and suffering Russian counter-sanctions. Similarly, the Greek Socialists and Macedonian Social Democrats, traditional Russian allies, have drifted away from their erstwhile Russophile feelings. Somewhere in the middle of the spectrum, the two most Western Balkan nations, Slovenia and Croatia, along with Bulgaria, while supporting sanctions, still insist on resuming dialogue with Russia. Two close Russian partners -Serbia and Bosnia- refused to support sanctions against Russia in 2014-2015. But even with this decision, President Vučić tried to keep a middle ground. On the one hand, Vučić refused to join sanctions against Russia, referring to close Russia-Serbs relations. ${ }^{61}$ On the other hand, Vučić highlighted that Serbia would stick to existing contracts and will not try to boost its exports to Russia to satisfy the growing demand in agricultural products in Russia. ${ }^{62}$

In 2014-2016, it was comparatively easy for Serbia and Bosnia to maintain a middle ground between Russia and Europe. At that point, the EU was still 


\section{The fact that Russia values its great power status more than its friendship with Montenegro or Greece has resulted in these countries' further drift to the EU and NATO, respectively}

undecided about membership prospects for the Balkan states. Therefore, both the West and Russia viewed the region with lesser interest. Interaction in the triangle of Russia-Balkans-West was shaped by a series of occasional mutually-beneficial deals and a general discourse of friendship and peace. The situation changed in February 2018 when the EU adopted the Communication for Western Balkans, which provided the countries of the region with a membership prospect and clear date of 2025 . $^{63}$ The balance of indifference has been disrupted, and the countries of the region will have to face the growing tension between compliance with EU norms in foreign and internal politics and the threat of potential Russia's countermeasures. This may lead to further deterioration of the situation in the region and inside some of the countries of the region.

\section{Conclusions}

Despite its high visibility, Russia's recent return to the Balkans reveals serious limitations for Russian policy, and tensions between Moscow and the Balkan capitals. The primary underlying factor, which has a limited possibility of a genuine Russian-Balkan alliance, is the fact that historically Moscow has placed a higher value on participation in the great power concerts than friendship with the countries of the region. Within this logic, Moscow has been and remains prepared to prioritize its relations with the West over the interests of its allies in the Balkans. Moreover, it is often prepared to use its influence in the region to generate instability in order to 'socialize the West' into accepting Russia's primary role in the region. Despite the growing symbolic presence of Russia, the nations of the region -fully aware of and disappointed in its policies- have now adopted a more skeptical attitude toward Russia. The fact that Russia values its great power status more than its friendship with Montenegro or Greece has resulted in these countries' further drift to the EU and NATO, respectively.

The second important factor limiting Russia's influence in the Balkans is the nature of the tools that it uses. Moscow seems to rely on the people and instruments that it uses in forging alliances and loyalty in its internal politics, i.e. corruption, an informal network of violent groups, and compromising 


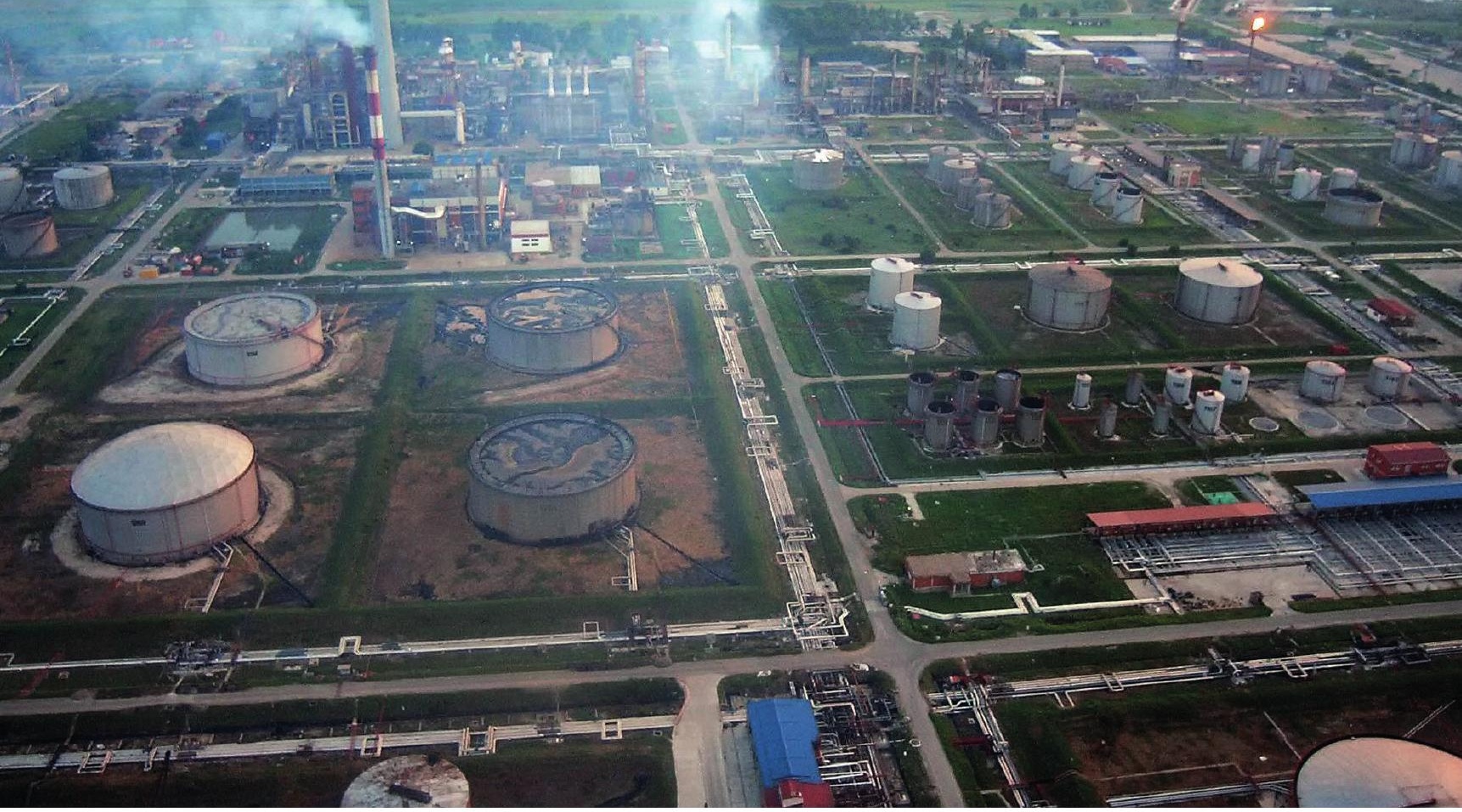

The picture shows a petroleum

materials. ${ }^{64}$ This method, however, is not similarly effective in international politics. Countries of the region clearly see the threat of Russia manipulating instability, and have drawn the line for Russia's penetration into these countries. Greece, North Macedonia, and even Moscow's closest allies had to draw a line in front of Russia's gradual penetration into the region. Serbia and Bosnia banned Russian paramilitary groups and pursued low-key (but intensive) collaboration with NATO. In Bosnia, pro-Russian candidates from the Serb and the Croat community lost elections; they were exposed for their pro-Russian attitudes and eventually lost their political positions. Additionally, reliance on dubious people and methods has made pro-Russian actors in the region vulnerable to corruption charges, sanctions, and public scandals. The West can effectively neutralize Russia's efforts, given its advanced access to the monitoring of financial flows from Russia to the region. In Bosnia, the ethno-nationalist leader of the Serb community Dodik had to abandon his projects after his dubious funding channels from Russia were revealed. North Macedonia opted for a reconciliation with Greece after it turned out that anti-Greek sentiment had been sponsored through Russian oligarchs on both sides of the border. The most successful of the countries of the region has been Serbia, which has managed to find an ideal mix of pro-Russian rhetoric and effective pro-Western policies.

For similar reasons, Russia's economic presence could not lead to deeper ties and more positive influence in the Balkans. While it may achieve certain success in energy cooperation, the fact that Moscow tends to attach political 
NATO's expansion to the Balkans will lock the region in the Euro-Atlantic security system and further undermine Russia's role in the region, potentially causing a serious identity crisis strings to energy collaboration often undermines any positive benefits that Russia could reap from such collaboration. The policies of the Russian energy champion Gazprom, which sought to fully control the pipelines that it builds, resulted in growing tensions between European regulations and the potential benefits countries of the regions could receive from such collaborations. With growing controversies and Russia's sensitivity, energy collaboration often loses its attractiveness. This is not to say that Russia will be squeezed out of the Balkan energy market. But it is clear that the countries of the region tend to increasingly rely on the European normative framework in energy deals with Russia, and engage in a growing pursuit of alternative energy supply from Europe and elsewhere. In this context, Russia -even if its energy supply to the Balkans remains at the same level- will find it difficult to turn its energy collaboration with the region into political influence. Similarly, Russia's trade is hampered by serious structural constrains that limit Russia's success in the region. The Russian market remains small for the Western Balkans; trade turn-over between Russia and the region constitutes only a fraction of their general trade. The EU's promise of membership and the inclusion of the Western Balkans in the EU's strategy of connectivity have made Russia even less relevant for the countries of the region. Moreover, the fact that many countries of the region agreed to support EU sanctions and suffer Russia's counter-sanctions has imposed further limits on their trade. Therefore, Russia-Balkans economic ties are not sufficiently dense to produce serious social and political effects.

This trend suggests that Russian presence in the Balkans is a troubled comeback, and not fully conducive to regional stability. NATO's expansion to the Balkans will lock the region in the Euro-Atlantic security system and further undermine Russia's role in the region, potentially causing a serious identity crisis. This is why Russia's response is to prevent NATO expansion by creating further instability, which it is in a prime position to do. In the post-Soviet space, some of the Balkan societies have constituencies that would "buy into" Russia's narratives drawing on Soviet nostalgia, ethno-nationalist trauma or conservative slogans. The high social costs of certain reforms might make local societies more prone to divisive rhetoric articulated by Russian media outlets. Moreover, the Ukrainian crisis has once again reconstituted the link between the events in the Black Sea region and the Balkans, fusing the two regions -as argued by a prominent Russian scholar- into one security complex, ${ }^{65}$ which will remain vulnerable to shocks coming either from the adjacent regions or from the broader context of Russian-Western interaction. 


\section{Endnotes}

1. The views expressed are purely those of the writer and may not in any circumstances be regarded as stating an official position of the European Commission.

2. See, Roy Allison, Russia, the West, and Military Intervention, (Oxford: Oxford University Press, 2013); Jeffrey Mankoff, Russian Foreign Policy: The Return of Great Power Politics, (Lanham, MD: Rowman \& Littlefield, 2009); Marcel de Haas, Russia's Foreign Security Policy in the 21 $1^{\text {st }}$ Century: Putin, Medvedev and Beyond, (London and New York: Routledge, 2010); James Sherr, Hard Diplomacy and Soft Coercion: Russia's Influence Abroad, (London: Chatham House, 2013).

3. Vsevolod Samokhvalov, "Russia and Its Shared Neighbourhoods: A Comparative Analysis of Russia-EU and Russia-China Relations in the EU's Eastern Neighbourhood and Central Asia," Contemporary Politics, Vol. 924, No.1 (2018), pp. 30-45.

4. Eduard Abrahamyan, "'Pax Russica' in the Balkans: Serbia between Myth and Reality," E-International Relations, (April 30, 2015), retrieved from https://www.e-ir.info/2015/04/30/pax-russica-in-the-balkansserbia-between-myth-and-reality/.

5. An empirically rich, but largely descriptive account can be found in James Headley, Russia and the Balkans: Foreign Policy from Yeltsin to Putin, (New York, NY: Columbia University Press, 2008).

6. Vsevolod Samokhvalov, Russian-European Relations in the Balkans and the Black Sea Region: Great Power Identity and the Idea of Europe, (Palgrave: Basingstoke, 2017).

7. Elena Smilyanskaya, "Russian Warriors in the Land of Militates and Themistocles: The Colonial Ambitions of Catherine the Great in the Mediterranean," HSE Working Papers, No. WP BRP 55/HUM/2014, (May $13,2014)$, retrieved from https://papers.ssrn.com/sol3/papers.cfm?abstract_id=2436332\#\#.

8. Samokhvalov, Russian-European Relations in the Balkans and the Black Sea Region.

9. Samokhvalov, Russian-European Relations in the Balkans and the Black Sea Region, p. 132.

10. Mike Bowker, "The Wars in Yugoslavia: Russia and the International Community," Europe-Asia Studies, Vol. 50, No. 7 (1998), p. 1257.

11. Samokhvalov, Russian-European Relations in the Balkans and the Black Sea Region, p. 132.

12. Henry H. Perritt, Jr., The Road to Independence for Kosovo: A Chronicle of the Ahtisaari Plan, (Cambridge: Cambridge University Press, 2010), pp. 126-160. Thanks to Hubertus Juergenlienk for bringing this to my attention.

13. "Foreign Policy Concept of the Russian Federation," MIDRU, (December 1, 2016), retrieved from http://www.mid.ru/foreign_policy/official_documents/-/asset_publisher/CptICkB6BZ29/content/id/ 2542248.

14. Ekaterina Entina et al., "Russian in the Balkans," Russian International Affairs Council, retrieved from https://russiancouncil.ru/en/balkans\#2a.

15. Dimitar Bechev, Rival Power: Russia's Influence in Southeast Europe, (New Haven: Yale University Press, 2017).

16. Viatcheslav Morozov, Russia's Postcolonial Identity: A Subaltern Empire in a Eurocentric World, (Basingstoke, New York: Palgrave Macmillan, 2015).

17. Samokhvalov, Russian-European Relations in the Balkans and the Black Sea Region, pp. 169-209.

18. Maxim Samorukov, "Russia's Tactics in the Western Balkans," Carnegie Europe, (November 3, 2017), retrieved from http://carnegieeurope.eu/strategiceurope/74612.

19. Bechev, Rival Power.

20. While for some analysts Montenegro's decision to join NATO came as a surprise, a recent country-focused analysis has shown that this smallest and historically closest-to-Moscow Balkan nation reconsidered its foreign policy course precisely because Montenegrin elites were disappointed by Russia's fixation on Serbia and preferred to take a course for rapprochement with Europe after the EU brokered the 2002 Belgrade Agreement which effectively led to the independence of Macedonia. See, Jelena 
Džankić, "From Creeping to Sprinting: Foreign Policy of Montenegro," in Bernhard Stahl and Soeren Keil (eds.), Foreign Policy of Yugoslav States, (Palgrave: Macmillan, 2014), pp. 173-195.

21. "Заявление Сергея Лаврова о Македонии [Sergey Lavrov's Statement about Macedonia]," RUS BG YouTube Channel, (May 20, 2015), retrieved from https://www.youtube.com/watch?v=ta_TtCsvXJo.

22. Probably one of the most detailed analyses of the influence of Ivan Savvides in the broader Black Sea area is, Alexander Clapp, "From Russia with Love: The New Greek Oligarchy," The American Interest, (January 5, 2018), retrieved from https://www.the-american-interest.com/2018/01/05/new-greekoligarchy/.

23. Andrey Zakharov, "Rassledovanie RBK: Kak Rosianin Stal Samym Bogatym Chelovekom Makedonii," RBK, (September 26, 2017), retrieved from https://www.rbc.ru/magazine/2017/10/59c2aa029a79473e 38382464.

24. Videos featuring Samsonenko were used for VRMO electoral videos; see, "Сергеј Самсоненко [Sergey Samsonenko]," ВМРО - ДПМНЕ YouTube Channel, (April 9, 2014), retrieved from https://www. youtube.com/watch?v=kqfBSrfJTp0.

25. Gorazd Velkovski, "Samsonenko with a Veiled 'F*ck You' to Zaev: I Am Staying in Macedonia," Mina Report, (September 15, 2017), retrieved from http://www.minareport.com/2017/09/15/samsonenko-witha-veiled-fck-you-to-zaev-i-am-staying-in-macedonia/; Saska Cvetkovska, "Russian Businessman Behind Unrest in Macedonia," OCCRP, (July 16, 2018), retrieved from https://www.occrp.org/en/28-ccwatch/ cc-watch-indepth/8329-russian-businessman-behind-unrest-in-macedonia.

26. Helene Cooper and Eric Schmitt, "U.S. Spycraft and Stealthy Diplomacy Expose Russian Subversion in a Key Balkan Vote," The New York Times, (October 8, 2018), retrieved from https://www.nytimes. com/2018/10/09/us/politics/russia-macedonia-greece.html.

27. "Lavrof: Me Hrimatismo kai Ekviasmo Voylefton sta Skopia Perasan oi Allages sto Syntagama," Kathimerini, (December 7, 2018), retrieved from http://www.kathimerini.gr/998863/article/epikairothta/ politikh/lavrof-me-xrhmatismo-kai-ekviasmo-voyleytwn-sta-skopia-perasan-oi-allages-sto-syntagma.

28. "Moskva Nikogda ne Vystupala Priot Novogo Nazvania Makedonia Zaiavil Lavrov," RIA Novosti, (January 16, 2019), retrieved from https://ria.ru/20190116/1549425632.html.

29. David Salvo and Stephanie De Leon, "Russia's Efforts to Destabilize Bosnia and Herzegovina," Alliance for Security Democracy GMF, Brief No. 17, (2018), retrieved from https://d2llho1jqyw8vm.cloudfront.net/ wp-content/uploads/2018/06/Bosnia-Policy-Brief_0-1.pdf.

30. Jasmin Mujanovic, "Russia's Bosnia Gambit," Foreign Affairs, (September 6, 2017), retrieved from https://www.foreignaffairs.com/articles/bosnia-herzegovina/2017-09-06/russias-bosnia-gambit.

31. Salvo and De Leon, "Russia's Efforts to Destabilize Bosnia and Herzegovina."

32. Marcus Tanner, "Bosnia Lost Enthusiasm for EU, Dodik Claims," Balkan Insight, (September 17, 2018), retrieved from https://balkaninsight.com/2018/09/17/bosnia-lost-enthusiasm-for-eu-dodik-claims-0917-2018/.

33. "New Presidency Member: I'm Loyal to Bosnia, Not Croatia," N1, (October 10, 2018), retrieved from http://hr.n1 info.com/English/NEWS/a338710/New-Presidency-member-I-m-loyal-to-Bosnia-notCroatia.html.

34. "Communique of the Holy Council of the Serb Orthodox Church," (April 19, 2018), retrieved from http://spc.rs/sr/saopshtenje_za_javnost_svetog_arhijerejskog_sabora_srpske, (in Serbian); Dmitri Horevoi, "Church Geopolitics: Position of the Church of Serbia," Religious Information Service of Ukraine, (May $11,2018)$, retrieved from https://risu.org.ua/ru/index/expert_thought/open_theme/71118.

35. "His Holiness Patriarch Kirill Meets Primate of the Serbian Orthodox Church," Patriarchia.ru, (May 23, 2018), retrieved from http://www.patriarchia.ru/db/text/5208760.html, (in Russian); "Joint News Conference with President of Serbia Aleksandar Vucic and President of Russia Vladimir Putin," President of Russia, (January 17, 2019), retrieved from http://en.kremlin.ru/events/president/news/59693.

36. "Relations with Serbia," NATO, (March 26, 2019), retrieved from https://www.nato.int/cps/en/natohq/ topics_50100.htm. 
37. Vincent L. Morelli, "The Balkans and Russia Insight," The CRS Insight, (January, 31, 2018), retrieved from https://fas.org/sgp/crs/row/IN10851.pdf.

38. "Interivew: Aleksandar Vucic: Putin Is Serbia's Friend, but He Respects Our Path to Europe," Elpais, (May 18, 2018), retrieved from https://elpais.com/elpais/2018/05/18/inenglish/1526628902_698612. html.

39. "Deca u Uniformana na Zlatibory - o Cemu se Radi," B92, (August 16, 2018), retrieved from https:// www.b92.net/info/vesti/index.php?yyyy=2018\&mm=08\&dd=15\&nav_category=12\&nav_id=1431321.

40. "Valeriy Shambarov," Likorg, retrieved from http://likorg.ru/valeriy-shambarov.

41. "Ratne igre tinejdžera iz Srbije Roditelji šalju decu u kamp ruskih ultranacionalista da uče da pucaju iz snajpera," Blic, (April 8, 2019), retrieved from https://www.blic.rs/vesti/svet/ratne-igre-tinejdzera-izsrbije-roditelji-salju-decu-u-kamp-ruskih-ultranacionalista/yfmk9b3.

42. "Zabrana za vojni kamp za decu Policija kasno sinoć ušla u kamp na Zlatiboru i zatvorila ga," Blic, (August 17, 2018), retrieved from https://www.blic.rs/vesti/drustvo/zabrana-za-vojni-kamp-za-decupolicija-kasno-sinoc-usla-u-kamp-na-zlatiboru-i/yk40hrn.

43. Semir Mujkic, "Bosnian Branch of 'Putin's Angels' Enjoys Political Backing," The Balkan Insight, (March 15, 2019), retrieved from https://balkaninsight.com/2019/03/15/bosnian-branch-of-putins-angels-enjoys-political-backing/.

44. The organizational structure is available here: http://www.ippo.ru/about/article/organizacionnaya-struktura-ippo-200324. Most recently IOPS established its filial in the UK, "Mission of Imperial Orthodox Palestine Society Established In UK," Russkiymir, (February 21, 2019), retrieved fromhttps:// russkiymir.ru/en/news/252921/.

45. "Russian Spies in Construction Ellaktor?" lefimerida, (July 19, 2018), retrieved from http://www.iefimerida.gr/news/431882/rosoi-kataskopoi-stin-kataskeyastiki-ellaktor, (in Greek).

46. While it is difficult to trace links to the activities of the IOPS in the $19^{\text {th }}$ century, the newly-founded society continues its activities and it was covered by the "Putting National Interest First: Soberly and Firmly," Ministry of Foreign Affairs of Greece, (August 10, 2018), retrieved from https://www.mfa.gr/en/ current-affairs/statements-speeches/putting-national-interest-first-soberly-and-firmly.html.

47. Interview with official of the Hellenic Ministry of Foreign Affairs, (November 20, 2018).

48. "Greece Stopped Issuing Visas to Priests from Russia," Fakty Newspaper, (August 9, 2018), retrieved from http://fakty.ua/277570-greciya-perestala-vydavat-vizy-svyacshennikam-iz-rossii, (in Russian); Jeremy Norman, "What Is behind Vladimir Putin's Curious Interest in Mount Athos?" Spectator, (September 10, 2016), retrieved from https://www.spectator.co.uk/2016/09/what-is-behind-vladimir-putins-curious-interest-in-mount-athos/.

49. “Kammenos Proposes US Bases in Volos, Alexandroupoli and Larissa," Kathimerini, (October 10, 2018), retrieved from http://www.ekathimerini.com/233472/article/ekathimerini/news/kammenos-proposes-us-bases-in-volos-alexandroupoli-and-larissa.

50. Paul Kandel, "'Balkanizatsiya Evropy' vs. 'Evropeizatsiya' Balkan," Rossiya v Globalnoi Politike, (June 2008), retrieved from http://www.globalaffairs.ru/ number/n_10945; M. Sokolov, "Evropa Est' A Schastia Netu," Izvestia, (May 15, 2007).

51. Ivan Krastev and Stephen Holmes, "Explaining Eastern Europe: Imitation and its Discontents," Journal of Democracy, Vol. 29, No. 3 (2018), pp. 117-128.

52. "Remarks by President Barroso Ahead of the G7 Summit," European Commission, (June 4, 2014), retrieved from http://europa.eu/rapid/press-release_SPEECH-14-430_en.htm.

53. "Russia Drops South Stream Gas Pipeline Plan," $B B C$, (December 1, 2014), retrieved from https://www. bbc.com/news/world-europe-30283571.

54. Julija Simic, "Serbia Snags Piece of Turkish Stream Pipeline Pie," EurActiv, (February 15, 2019), retrieved from https://www.euractiv.com/section/energy/news/serbia-snags-piece-of-turkish-streampipeline-pie/. 
55. Sergey Sutyrin et al., "Russian Investments in the Balkans: Expectations and Realities - the Special Case of Lukoil," Journal of East-West Business, (2018), retrieved from https://doi.org/10.1080/10669868.2 018.1467844 .

56. Georgi Gotev, "US Warns Hungary and Neighbours against Turkish Stream," EurActiv, (November 14, 2018), retrieved from https://www.euractiv.com/section/global-europe/news/us-warns-hungary-andneighbors-against-turkish-stream/.

57. Džankić, "From Creeping to Sprinting."

58. Sutyrin et al., "Russian Investments in the Balkans."

59. M. Maksakova, "Vneshneekonomischeskoe Sotrudnichestvo Rossii I Serbii; sostoianie I perspektivy razvitia, Rossiyskiy Vneshneekonomicheskiy Vestnik," (2014), pp. 104-116, https://mgimo.ru/upload/ diss/2015/Maksakova_Avtoreferat.pdf.

60. "Connecting Europa and Asia: Building Blocks for EU Strategy," Joint Communication to the European Parliament, the Council, the European Economic and Social Committee, The Committee of the Regions and the European Investment Bank, (September 19, 2018), retrieved from https://eeas.europa.eu/sites/ eeas/files/joint_communication_-_connecting_europe_and_asia_-_building_blocks_for_an_eu_strategy_2018-09-19.pdf.

61. "Serbia Refuses to Join EU Sanctions on Eve of Putin Parade," Euobserver, (October 15, 2014), retrieved from https://euobserver.com/foreign/126078.

62. Aleksandar Vasovic, "EU Candidate Serbia Says It will not Exploit Russian Embargo," Reuters, (August 22, 2014), retrieved from https://www.reuters.com/article/us-ukraine-crisis-sanctions-serbia/eu-candidate-serbia-says-will-not-exploit-russian-embargo-idUSKBNOGM12120140822.

63. "A Credible Enlargement Perspective for and Enhanced EU Engagement with the Western Balkans," European Commission, (February 6, 2018), retrieved from https://ec.europa.eu/commission/sites/betapolitical/files/communication-credible-enlargement-perspective-western-balkans_en.pdf.

64. For more details see, AlenaV. Ledeneva, Can Russia Modernise? Sistema, Power Networks and Informal Governance, (Cambridge: Cambridge University Press, 2013).

65. Nadia Arbatova, "Russia and NATO in South Eastern Europe," in N. Kovalsky (ed.), Europe, The Mediterranean and Russia: Perceptions and Strategies, (Moscow: Interdialect for Institute of Europe: RAN, 1998). 